\title{
Non-genetic factors affecting growth performance and carcass characteristics of two South African pig breeds
}

\author{
B. Dube ${ }^{1 \#}$, S.D. Mulugeta ${ }^{1}$, R.R. van der Westhuizen ${ }^{2}$ \& K. Dzama ${ }^{3}$ \\ ${ }^{1}$ Animal Science Programme, North West University, Private Bag X2046, Mmabatho 2735, South Africa \\ ${ }^{2}$ ARC Livestock Business Division, Private Bag X2, Irene 0062, South Africa \\ ${ }^{3}$ Department of Animal Sciences, Stellenbosch University, Private Bag X1, Matieland 7602, South Africa
}

Copyright resides with the authors in terms of the Creative Commons Attribution 2.5 South African Licence.

See: http://creativecommons.org/licenses/by/2.5/za/

Condition of use: The user may copy, distribute, transmit and adapt the work, but must recognise the authors and

the South African Journal of Animal Science

\begin{abstract}
A study was conducted to establish non-genetic factors affecting growth and carcass traits in Large White and Landrace pigs. This study was based on 20079 and 12169 growth and 5406 and 2533 carcass data collected on performance tested pigs between 1990 and 2008 from Large White and Landrace breeds respectively. The traits analyzed were backfat thickness (BFAT), test period gain (TPG), lifetime gain (LTG), feed conversion ratio (FCR), age at slaughter (AGES), lean percentage (LEAN), drip-free lean percentage (DLEAN), drip loss (DRIP), dressing percentage (DRESS), carcass length (CRLTH) and eye muscle area (AREA). Significant effects were determined using PROC GLM of SAS. Herd of origin, year of testing and their interaction significantly affected all traits. Most traits were not affected by season of testing in both breeds, while all traits in both breeds were significantly affected by sex. Testing environment (station, farm) affected all growth traits except for LTG. Backfat thickness and AGES increased with increasing total feed intake, while other traits decreased as total feed intake increased. Improved test centre management did not compensate for pre-test underperformance. Castrates produced higher carcass yields of lower quality than females, while performance testing showed the best results when done at testing centres. This study showed the importance of adjusting for fixed effects when performing genetic evaluations in the two pig populations.
\end{abstract}

Keywords: Carcass traits, growth traits, environmental effects, Large White, Landrace, swine

\#Corresponding author: Bekezela.Dube@nwu.ac.za

\section{Introduction}

The value of a meat animal is realized when its product is marketed and expressed relative to the input costs incurred. Growth and its associated traits in pigs reflect to a certain degree the value of the animal; hence live measurements can be used to evaluate an animal. Valuable pigs are the ones which, for each unit of food energy, waste least in such processes as digestion and physical activity, and retain most by favouring conversion of metabolizable energy to lean than conversion to fat tissue (Webster, 1977). This has desirable implications on enterprise profit, as feed constitutes a large portion $(60-70 \%)$ of pig enterprise costs (Hoque et al., 2007). Thus, pig characteristics that are positive for profitability, are high growth rate, food conversion ratio and low carcass fatness (McPhee \& MacBeth, 2000). Improvement has been achieved in some breeding programmes through selection for lean growth rate (McPhee et al., 1991; Cameron, 1994).

Success of these breeding programmes is facilitated by the variation that exits in growth and carcass traits in pigs. This variation can be partitioned into genetic and environmental components. Environmental variance, albeit not transferable from parent to offspring, plays an important part in the performance of livestock and their products. Knowledge of non-genetic factors helps in standardizing management of the 
breeding animals. Some non-genetic effects, such as farm, sex and age on growth and carcass traits have been reported in the literature for sheep (Cassady et al., 2004), pigs (Mungate et al., 1999; Serrano et al., 2008), goats (Maghoub et al., 2004) and cattle (Nephawe et al., 2006). It is therefore imperative that nongenetic factors be considered in livestock improvement programmes to accurately estimate breeding values.

Therefore, proper identification and estimation of non-genetic effects on growth and carcass traits being evaluated, is a necessity in pig improvement schemes. There is a paucity of information on non-genetic factors affecting carcass characteristics of centrally tested pigs in South Africa. The purpose of this study was to evaluate non-genetic effects on growth and carcass traits within the two major South African commercial pig breeds.

\section{Materials and Methods}

The South African Pig Performance Testing Scheme is conducted to extend and improve the National Pig Herd by means of scientifically founded and proven methods and practices. Performance testing occurred throughout the year on castrates and females, such that at any point in the year there were animals being tested. The animals were tested and slaughtered at three testing centres, namely Irene, Elsenburg and Cedara. Records available from performance testing are for Phases B and D of the Scheme. Phase B testing is the central boar and gilt performance and carcass quality test phase conducted at the testing centres named above. On the other hand, Phase D is the on-farm testing of pigs. Under the Phase B, each member submitted 44 pigs (22 boars and 22 gilts) for testing every year. These 44 pigs were to represent a minimum of five herd sires per breed or line, or 50\% of the herd sires per breed or line. On arrival, pigs were treated for internal and external parasites and quarantined under the supervision of the responsible State veterinarian. All pigs were randomly selected at the test station for performance testing between 18 and $24 \mathrm{~kg}$ without considering representation of herds, sires or lines. The animals were individually penned and fed until they commenced testing at mean weights of 29.7 and $29.5 \mathrm{~kg}$ for the Large White and Landrace breeds respectively. Animals were kept on solid concrete floors. When testing commenced, the pigs were individually fed ad libitum using self feeders and water was also available ad libitum during the test period. Total feed intake from the beginning of the test to $86 \mathrm{~kg}$ body weight was calculated at the end of the test period. Parameters of growth rate, feed consumption and age at slaughter (86 kg) were measured on these animals. Backfat measurements were taken using a Backfat Scanner A100 probe at $77 \mathrm{~kg}$ and at slaughter (86 kg) at the T23 position, which was $6.5 \mathrm{~cm}$ from the midline between the second and third last rib. Weighing was done weekly during the test period, without any change in the feeding routine and performance testing was completed at a live weight of $86 \mathrm{~kg}$. The Phase D scheme involves on-farm performance testing of boars and gilts, measuring growth rate, ultrasonic backfat measurements and, where possible, feed intake and feed conversion ratio.

Animals from the performance testing scheme (Phase B) were randomly selected for carcass evaluation. The animals were electrically stunned with $250 \mathrm{~V}$ for $7-10 \mathrm{sec}$. Animal ethics approval was obtained from the Agricultural Research Council Animal Ethics Committee. This was followed by the scraping and removal of the entrails. A State veterinarian or meat inspector performed the necessary inspection of the carcass after slaughtering. The carcasses were then hung for $24 \mathrm{~h}$ in a cold storage room for chilling. The carcases were then split vertically along the midline. A loin sample, approximately $2 \mathrm{~cm}$ thick and $15 \mathrm{~cm}$ long, was dissected at the T23 position. The average mass of the loin samples was recorded in grams. Each loin sample was placed in a nelton bag and tied accordingly to prevent the loin sample touching the bottom of the barrier bag or air coming into the barrier bag. The mass of each new empty and clean barrier bag was obtained in grams before placing in the loin sample. This parcel was stored in a refrigerator between 0 and $5{ }^{\circ} \mathrm{C}$ for $48 \mathrm{~h}$, after which the loin sample in the nelton bag was removed from the barrier bag. The mass of the barrier bag, which included exudates collected as drip, was recorded in grams. Measurements for the T23 fat and muscle were taken using an ultrasonic probe at the T23 position.

The data incorporated 20079 and 12169 growth performance records and 5406 and 2533 carcass records for Large White and Landrace pig breeds, respectively. The growth performance data for Large White and Landrace were from 29 and 21 herds, respectively, while the carcass data were from 20 and 13 herds. These data were obtained from the Integrated Recording and Genetic Information Systems (INTERGIS) database. These animals were tested between 1990 and 2008 and carcass evaluated between 1993 and 2007. Carcass length and eye muscle area were evaluated between 1998 and 2007, hence they had 2267 and 1011 records, respectively, for Large White and Landrace pigs. 
Table 1 Summary statistics of growth and carcass traits and covariates for Large White (above) and Landrace (below) pigs

\begin{tabular}{|c|c|c|c|c|c|}
\hline & $\mathrm{N}$ & Mean & Min & Max & SD \\
\hline \multirow[t]{2}{*}{ BFAT (mm) } & 20079 & 12.3 & 7.0 & 24.0 & 2.9 \\
\hline & 12169 & 15.6 & 6.0 & 27.0 & 2.9 \\
\hline \multirow[t]{2}{*}{ TPG (g/day) } & 20079 & 1019.0 & 690.5 & 1327.0 & 107.3 \\
\hline & 12169 & 941.4 & 654.8 & 1265.0 & 105.2 \\
\hline \multirow[t]{2}{*}{ LTG (g/day) } & 20079 & 676.6 & 524.4 & 814.2 & 50.3 \\
\hline & 12169 & 644.3 & 508.8 & 804.4 & 49.8 \\
\hline \multirow[t]{2}{*}{ FCR } & 20079 & 2.08 & 1.41 & 3.12 & 0.31 \\
\hline & 12169 & 2.32 & 1.63 & 3.04 & 0.19 \\
\hline \multirow[t]{2}{*}{ AGES (days) } & 20079 & 127.7 & 106.0 & 164.0 & 10.2 \\
\hline & 12169 & 107.0 & 134.3 & 169.0 & 10.2 \\
\hline \multirow[t]{2}{*}{ LEAN (\%) } & 5406 & 69.2 & 65.0 & 72.0 & 1.4 \\
\hline & 2533 & 68.4 & 63.0 & 73.0 & 1.5 \\
\hline \multirow[t]{2}{*}{ DLEAN (\%) } & 5406 & 56.8 & 52.0 & 61.0 & 2.0 \\
\hline & 2533 & 55.6 & 48.0 & 63.0 & 2.0 \\
\hline \multirow{2}{*}{ DRIP (\%) } & 5406 & 3.08 & 0.29 & 5.46 & 2.03 \\
\hline & 2533 & 3.96 & 1.00 & 6.30 & 1.97 \\
\hline \multirow[t]{2}{*}{ DRESS (\%) } & 5406 & 77.6 & 69.0 & 85.0 & 3.0 \\
\hline & 2533 & 76.4 & 69.0 & 84.0 & 3.2 \\
\hline \multirow[t]{2}{*}{ CRLTH (cm) } & 2267 & 77.2 & 65.0 & 85.0 & 2.1 \\
\hline & 1011 & 78.2 & 70.0 & 85.0 & 2.2 \\
\hline \multirow[t]{2}{*}{$\operatorname{AREA}\left(\mathrm{cm}^{2}\right)$} & 2267 & 40.0 & 19.3 & 64.4 & 5.8 \\
\hline & 1011 & 43.2 & 24.0 & 61.7 & 6.1 \\
\hline \multirow[t]{2}{*}{ FEED (kg) } & 20079 & 140.1 & 95.5 & 185.5 & 15.0 \\
\hline & 12169 & 144.1 & 99.5 & 198.5 & 17.3 \\
\hline \multirow[t]{2}{*}{ AGEB (days) } & 20079 & 70.7 & 51.0 & 92.0 & 6.2 \\
\hline & 12169 & 68.8 & 51.0 & 88.0 & 5.9 \\
\hline \multirow[t]{2}{*}{ STWT (kg) } & 20079 & 29.7 & 25.0 & 32.0 & 1.8 \\
\hline & 12169 & 29.5 & 27.0 & 32.0 & 1.7 \\
\hline
\end{tabular}

N - number of records; SD - standard deviation; BFAT - backfat thickness; TPG - test period weight gain; LTG weight gain from birth to slaughter; FCR - feed conversion ratio during test; AGES - age at slaughter; LEAN - lean percentage; DLEAN - drip-free lean; DRIP - drip loss; CRLTH - carcass length; DRESS - dressing percentage; AREA - eye muscle area; FEED - total test period feed intake; AGEB - age at the beginning of test period; STWT - weight at the start of the test period.

The growth traits analyzed were ultrasonic backfat thickness (BFAT), test period weight gain (TPG), lifetime weight gain (LTG), test period feed conversion ratio (FCR), which was computed as the amount of feed consumed to gain one kg body mass, and age at slaughter (AGES). Analysis of carcass traits were done on lean percentage (LEAN), drip-free lean percentage (DLEAN), drip loss (DRIP), dressing percentage (DRESS), carcass length (CRLTH) and eye muscle area (AREA). DRESS was calculated by expressing cold 
carcass weight (carcass weight after chilling) as a percentage of weight at slaughter. CRLTH was measured from the anterior edge of the first rib to the pubic bone using a measuring tape. AREA was determined using a square grid. The summary statistics for the traits analyzed are shown in Table 1. LEAN, DLEAN and DRIP were calculated using the following formulae (Equations 1 to 3), respectively (Bruwer, 1992).

$$
\begin{aligned}
& \text { LEAN }(\%)=72.5114-(0.4618 \times \text { T23fat })+(0.0547 \times \text { T23muscle }) \\
& \text { DLEAN }(\%)=29.37+(0.56 \times \text { LEAN } \%)-3.1 \sqrt{(\text { T23fat })} \\
& \text { DRP }(\%)=\left(\frac{(\text { combined drip }(\mathrm{g})+\text { bag weight }(\mathrm{g}))-\text { bag weight }(\mathrm{g})}{\text { weight of chop sample }(\mathrm{g})}\right) \times 100
\end{aligned}
$$

where T23 fat and T23 muscle are fat and muscle thicknesses at the T23 position, respectively.

The original growth data contained 81411 and 22118 animal records for Large White and Landrace, respectively. Animals with missing feed intake and feed conversion records were removed, which amounted to 59089 and 11596 in Large White and Landrace, respectively. Original carcass data comprised of 5492 and 2585 records, respectively for Large White and Landrace pigs. These data were then edited to remove values that were greater or less than three standard deviations from the mean. The final data analyzed are shown in Table 1 . Animals with missing birth and testing dates were also removed. The data were checked for normality. Seasons of testing were defined as season 1 (October - March) and season 2 (April September). The significant effects of covariates on each trait were determined using PROC REG of SAS (SAS, 2003) by checking for independency and multicolinearity among covariates. Then the covariates which had significant effects on the response variable were taken to the GLM Procedures of SAS (SAS, 2003), where they were combined with class variables to get the final model for each trait. Effects of interactions between independent variables were also determined. Preliminary analyses showed no differences between growth or carcass traits due to test centre, suggesting uniformity in testing standards of the three testing stations. The following model equation (Equation 4) was used in the development of the models for all the traits:

$$
\mathrm{y}_{\mathrm{ijk} k \mathrm{~m}}=\mu+\mathrm{H}_{\mathrm{i}}+\mathrm{Y}_{\mathrm{j}}+\mathrm{S}_{\mathrm{k}}+\mathrm{SEX}_{\mathrm{l}}+\beta_{0}(\mathrm{TFI})_{\mathrm{ijklm}}+\beta_{1}(\mathrm{AGEB})_{\mathrm{ijklm}}+\mathrm{C}_{\mathrm{x}} \mathrm{C}_{\mathrm{y}}+\mathrm{e}_{\mathrm{ijklm}}
$$

where, $y_{i j k l m}$ is the observed trait, $H_{i}$ is the effect of the $i^{\text {th }}$ herd of origin, $Y_{j}$ is the effect of the $j^{\text {th }}$ year of testing, $S_{k}$ is the effect of the $\mathrm{k}^{\text {th }}$ season of testing, $S E X_{1}$ is the effect of the $\mathrm{l}^{\text {th }}$ sex of the animal, $\beta_{0}$ and $\beta_{1}$ are the regression coefficients of the observed trait on the respective covariate; (TFI) $)_{\mathrm{ijk} k m}$ is the test period total feed intake, (AGEB) $)_{\mathrm{ijklm}}$ is the age at the beginning of the test period, $\mathrm{C}_{\mathrm{x}} \mathrm{C}_{\mathrm{y}}$ is the interaction effects between each pair of effects and $\mathrm{e}_{\mathrm{ijklm}}$ is the random error term.

\section{Results and Discussion}

Herd of origin affected $(P<0.001)$ all growth and carcass traits in Large White and Landrace pigs. Table 2 shows the summary statistics of the Least Squares means for the growth and carcass traits in the two breeds. Differences in growth performance and carcass characteristics in pigs were attributable to the birth and rearing environment (Gentry et al., 2004). Herd performance differences may suggest carry-over effects from pre-test performance differences, which are a result of different environmental conditions. Growth performance is determined by muscle fibre characteristics (Larzul et al., 1997), which are programmed during the prenatal period (Foxcroft et al., 2006). Furthermore, muscle fibre type percentages are influenced by environmental factors (Gentry et al., 2004; Petersen et al., 1997). Bee (2004) observed the effect of gestation feeding on carcass quality of progeny. Thus, pre-test environment has an effect on growth and carcass attributes (Beattie et al., 2000; Gentry et al., 2002; 2004; Hansen et al., 2006). These results suggest that differences in growth performance may be due to differences in management practices applied on different farms. Management at different farms should be optimised to produce pigs that perform well during the growth period and produce desirable carcasses.

All growth and carcass traits in the two breeds were affected $(P<0.001)$ by year of testing. The Least Square means for the effect of year of testing on growth and carcass traits for the two breeds are shown in 
Table 2 Summary statistics of herd least squares means for growth and carcass traits for Large White (above) and Landrace (below) pigs

\begin{tabular}{|c|c|c|c|c|c|c|c|}
\hline Traits & $\begin{array}{c}\text { No } \\
\text { Herds } \\
\end{array}$ & $\mathrm{N}$ & $\begin{array}{c}\text { Overall } \\
\text { Mean }( \pm \mathrm{SE})\end{array}$ & $\mathrm{n}$ & $\begin{array}{c}\text { Min } \\
\text { Mean }( \pm \text { SE })\end{array}$ & $\mathrm{n}$ & $\begin{array}{c}\text { Max } \\
\text { Mean }( \pm \mathrm{SE})\end{array}$ \\
\hline BFAT (mm) & $\begin{array}{l}29 \\
21\end{array}$ & $\begin{array}{l}20079 \\
12169\end{array}$ & $\begin{array}{l}12.3 \pm 0.01 \\
12.5 \pm 0.02\end{array}$ & $\begin{array}{l}100 \\
154\end{array}$ & $\begin{array}{l}10.3 \pm 0.21 \\
11.7 \pm 0.18\end{array}$ & $\begin{array}{l}521 \\
221\end{array}$ & $\begin{array}{r}15.4 \pm 0.09 \\
14.4^{\mathrm{C}} \pm 0.15\end{array}$ \\
\hline TPG (g/day) & $\begin{array}{l}29 \\
21\end{array}$ & $\begin{array}{l}20079 \\
12169\end{array}$ & $\begin{array}{r}1010.4 \pm 0.58 \\
987.4 \pm 0.69\end{array}$ & $\begin{array}{l}757 \\
225\end{array}$ & $\begin{array}{l}893.1 \pm 3.60 \\
918.9 \pm 5.72\end{array}$ & $\begin{array}{c}5133 \\
154\end{array}$ & $\begin{array}{l}1059.1 \pm 1.78 \\
1013.2 \pm 7.28\end{array}$ \\
\hline LTG (g/day) & $\begin{array}{l}29 \\
21\end{array}$ & $\begin{array}{l}20079 \\
12169\end{array}$ & $\begin{array}{l}661.7 \pm 0.21 \\
664.4 \pm 0.25\end{array}$ & $\begin{array}{l}757 \\
225\end{array}$ & $\begin{array}{l}569.8 \pm 1.58 \\
606.4 \pm 2.58\end{array}$ & $\begin{array}{c}5133 \\
154\end{array}$ & $\begin{array}{l}704.7 \pm 0.78 \\
697.7 \pm 3.28\end{array}$ \\
\hline FCR & $\begin{array}{l}29 \\
21\end{array}$ & $\begin{array}{l}20079 \\
12169\end{array}$ & $\begin{array}{l}2.19 \pm 0.001 \\
2.13 \pm 0.001\end{array}$ & $\begin{array}{l}100 \\
132\end{array}$ & $\begin{array}{l}2.13 \pm 0.02 \\
2.04 \pm 0.02\end{array}$ & $\begin{array}{l}854 \\
393\end{array}$ & $\begin{array}{l}2.43 \pm 0.01 \\
2.34 \pm 0.01\end{array}$ \\
\hline AGES (days) & $\begin{array}{l}29 \\
21\end{array}$ & $\begin{array}{l}20079 \\
12169\end{array}$ & $\begin{array}{l}131.2 \pm 0.06 \\
130.2 \pm 0.05\end{array}$ & $\begin{array}{c}5133 \\
154\end{array}$ & $\begin{array}{l}122.3 \pm 0.16 \\
124.1 \pm 0.66\end{array}$ & $\begin{array}{l}757 \\
255\end{array}$ & $\begin{array}{l}150.7 \pm 0.32 \\
143.6 \pm 0.52\end{array}$ \\
\hline LEAN (\%) & $\begin{array}{l}20 \\
13\end{array}$ & $\begin{array}{l}5406 \\
2533\end{array}$ & $\begin{array}{l}68.6 \pm 0.02 \\
68.4 \pm 0.03\end{array}$ & $\begin{array}{c}220 \\
22\end{array}$ & $\begin{array}{l}67.4 \pm 0.11 \\
67.3 \pm 0.36\end{array}$ & $\begin{array}{c}345 \\
98\end{array}$ & $\begin{array}{l}69.5 \pm 0.09 \\
69.7 \pm 0.19\end{array}$ \\
\hline DLEAN (\%) & $\begin{array}{l}20 \\
13\end{array}$ & $\begin{array}{l}5406 \\
2533\end{array}$ & $\begin{array}{l}56.0 \pm 0.03 \\
55.5 \pm 0.04\end{array}$ & $\begin{array}{c}220 \\
22\end{array}$ & $\begin{array}{l}54.3 \pm 0.15 \\
54.0 \pm 0.50\end{array}$ & $\begin{array}{c}345 \\
98\end{array}$ & $\begin{array}{l}57.3 \pm 0.12 \\
57.7 \pm 0.25\end{array}$ \\
\hline DRIP (\%) & $\begin{array}{l}20 \\
13\end{array}$ & $\begin{array}{l}5406 \\
2533\end{array}$ & $\begin{array}{l}3.59 \pm 0.02 \\
4.04 \pm 0.05\end{array}$ & $\begin{array}{c}8 \\
13\end{array}$ & $\begin{array}{l}2.19 \pm 0.66 \\
2.48 \pm 0.66\end{array}$ & $\begin{array}{c}106 \\
98\end{array}$ & $\begin{array}{l}4.81 \pm 0.19 \\
6.94 \pm 0.27\end{array}$ \\
\hline DRESS (\%) & $\begin{array}{l}20 \\
13\end{array}$ & $\begin{array}{l}5406 \\
2533\end{array}$ & $\begin{array}{l}77.0 \pm 0.03 \\
76.5 \pm 0.05\end{array}$ & $\begin{array}{c}355 \\
70\end{array}$ & $\begin{array}{l}75.5 \pm 0.15 \\
75.6 \pm 0.34\end{array}$ & $\begin{array}{c}260 \\
70\end{array}$ & $\begin{array}{l}79.3 \pm 0.18 \\
77.7 \pm 0.24\end{array}$ \\
\hline CRLTH (cm) & $\begin{array}{l}7 \\
4\end{array}$ & $\begin{array}{l}2267 \\
1011\end{array}$ & $\begin{array}{l}77.3 \pm 0.04 \\
78.3 \pm 0.08\end{array}$ & $\begin{array}{l}220 \\
231\end{array}$ & $\begin{array}{l}75.9 \pm 0.45 \\
77.0 \pm 0.16\end{array}$ & $\begin{array}{c}8 \\
98\end{array}$ & $\begin{array}{l}78.7 \pm 0.79 \\
79.9 \pm 0.32\end{array}$ \\
\hline $\operatorname{AREA}\left(\mathrm{cm}^{2}\right)$ & $\begin{array}{l}7 \\
4\end{array}$ & $\begin{array}{l}2267 \\
1011\end{array}$ & $\begin{array}{l}40.4 \pm 0.11 \\
43.3 \pm 0.16\end{array}$ & $\begin{array}{c}8 \\
157\end{array}$ & $\begin{array}{l}35.4 \pm 1.87 \\
36.3 \pm 0.51\end{array}$ & $\begin{array}{l}345 \\
307\end{array}$ & $\begin{array}{l}43.7 \pm 0.48 \\
48.5 \pm 0.59\end{array}$ \\
\hline
\end{tabular}

SE - standard error; BFAT - backfat thickness; TPG - test period weight gain; LTG - weight gain from birth to slaughter; FCR - feed conversion ratio during test; AGES - age at slaughter; LEAN - lean percentage; DLEAN - dripfree lean; DRIP - drip loss; CRLTH - carcass length; DRESS - dressing percentage; AREA - eye muscle area.

Figures 1a to 1e and 2a to 2f. Generally, growth traits in the two breeds followed similar trends. The reduction in backfat thickness from 1990 to 2008 is desirable for consumers who prefer lean meat (Webb et al., 2006). There were decreasing trends for age at slaughter that favours farmers as fewer days to slaughter translate to less feed consumed. Feed cost constitutes about $60-70 \%$ of pig enterprise costs (Hoque et al., 2006). There were increases in both test period and lifetime weight gains from 1990 to 2000 as well as general increases in lean and drip-free lean from 1993 to 2007. Drip loss decreased in both breeds from 1993 to 1998, after which there was no discernible trend. A general decline in carcass yield was observed, depicted by a decreased carcass length in the Landrace breed and a reduced eye muscle area in the Large White breed. The jumps observed in drip loss and dressing percentages may be attributed to the amount of data collected that were not consistent (not presented) over the years. Since drip loss can only be determined in laboratories, there may have been inconsistent calculation of drip loss in some or all the testing centres. This may also be due to correlated responses to selection on different traits during different periods, when emphasis on traits might have varied. Although these animals were in total confinement, carry-over effects from their respective herds of origin may explain the observed differences during the years, as shown by the significant herd effect and its interaction with year of testing on growth and carcass traits (Cassady et al., 2004). These trends may also suggest changes due to selection and/or management practices. Growth 
traits have been reported to be heritable (Johnson et al., 1999; Nguyen \& McPhee, 2005; Oh et al., 2005; Chimonyo \& Dzama, 2007). Prenatal environmental influences may be exerted on growth and carcass characteristics (Foxcroft et al., 2006). Nilzen et al. (2001) and Gentry et al. (2002; 2004) observed the effect of birth and rearing environment on growth and carcass characteristics. These trends may also suggest response to selection on these or other correlated traits; hence improvement may be expected if the appropriate treatments are applied on them.

The effects of season of testing on growth and carcass traits for the two breeds are depicted in Table 3. Differences were observed in feed conversion ratio, with summer-tested pigs being more $(P<0.001)$ efficient than winter-tested pigs in both breeds, which is consistent with the findings of LeDividich et al. (1987). They attributed this to the fact that pigs eat more feed in cold weather to compensate for the greater metabolic demand for heat production. No significant effect $(P>0.05)$ of season of testing on backfat thickness, age at slaughter and weight gains in both breeds was observed. However, Chikwanha et al. (2007) reported an increase and decrease in body condition score in mature boars and lactating sows, respectively, due to season. Environmental temperature is known to affect the performance, voluntary energy intake and heat production of growing pigs (Close, 1987; Le Dividich et al., 1987; Bee, 2004). Landrace pigs tested in winter were leaner $(P<0.001)$ than their summer-tested counterparts. Trezona et al. $(2004)$ observed that

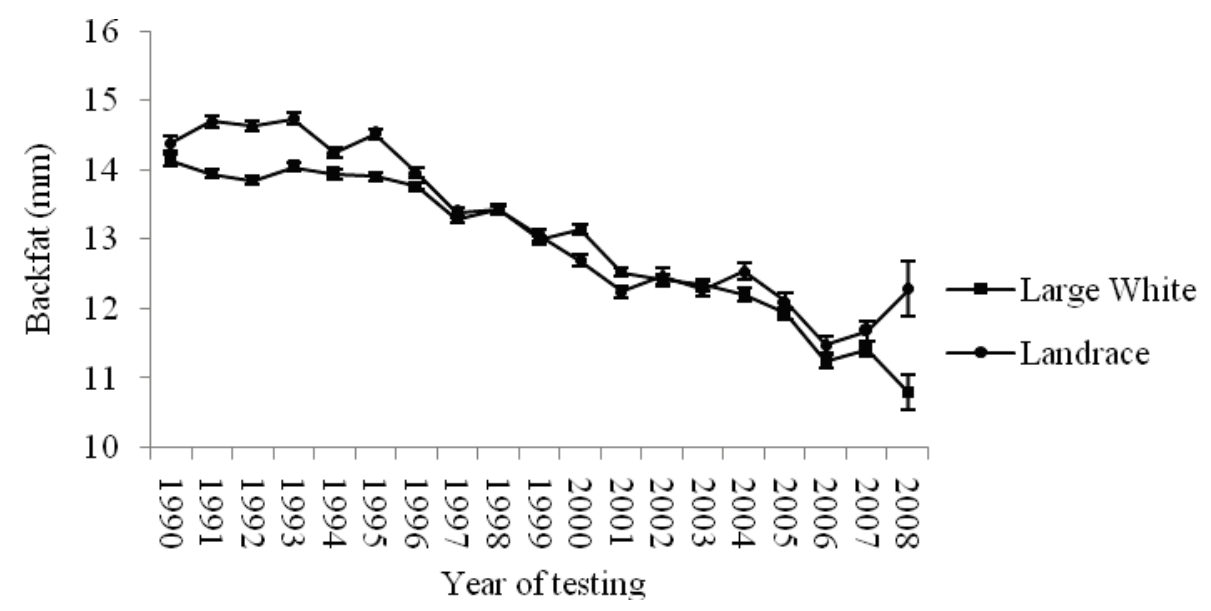

Figure 1a Phenotypic trend of backfat thickness in Large White and Landrace pigs.

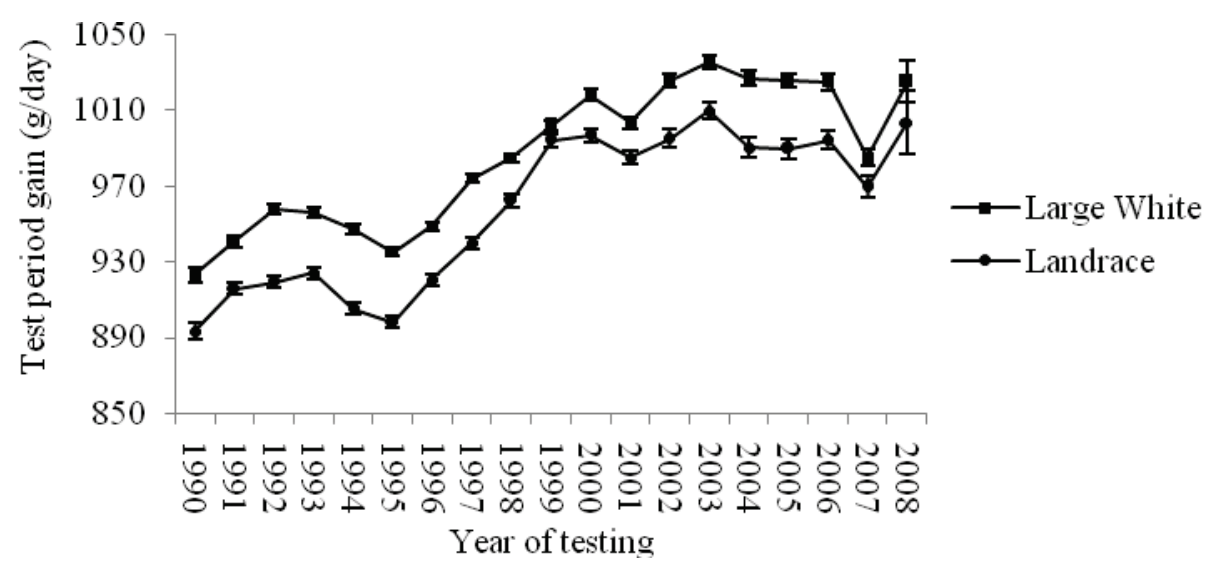

Figure 1b Phenotypic trend of test period weight gain in Large White and Landrace pigs. 


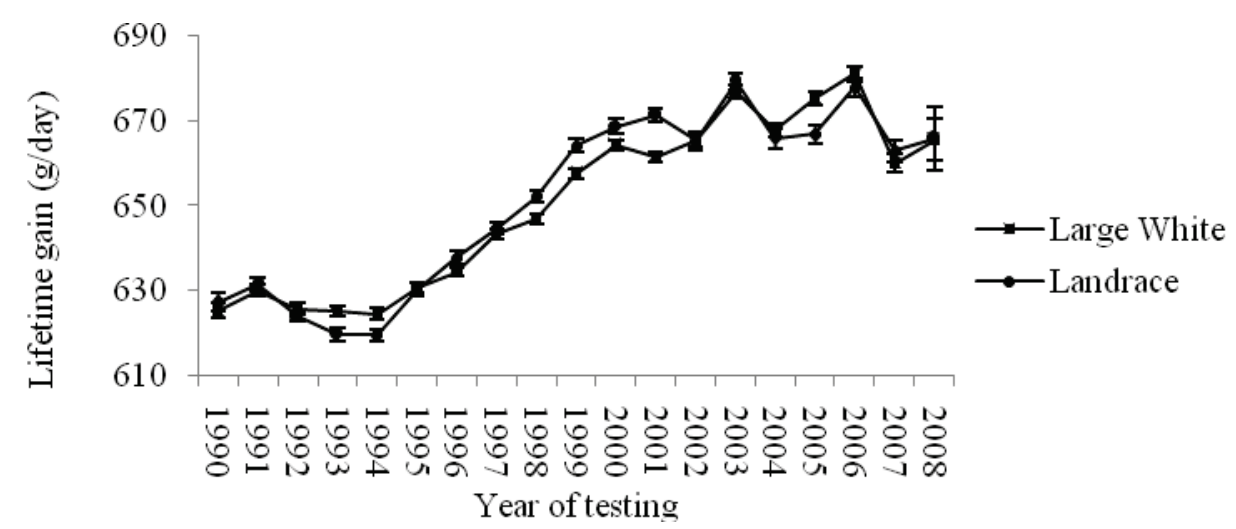

Figure 1c Phenotypic trend of lifetime weight gain in Large White and Landrace pigs.

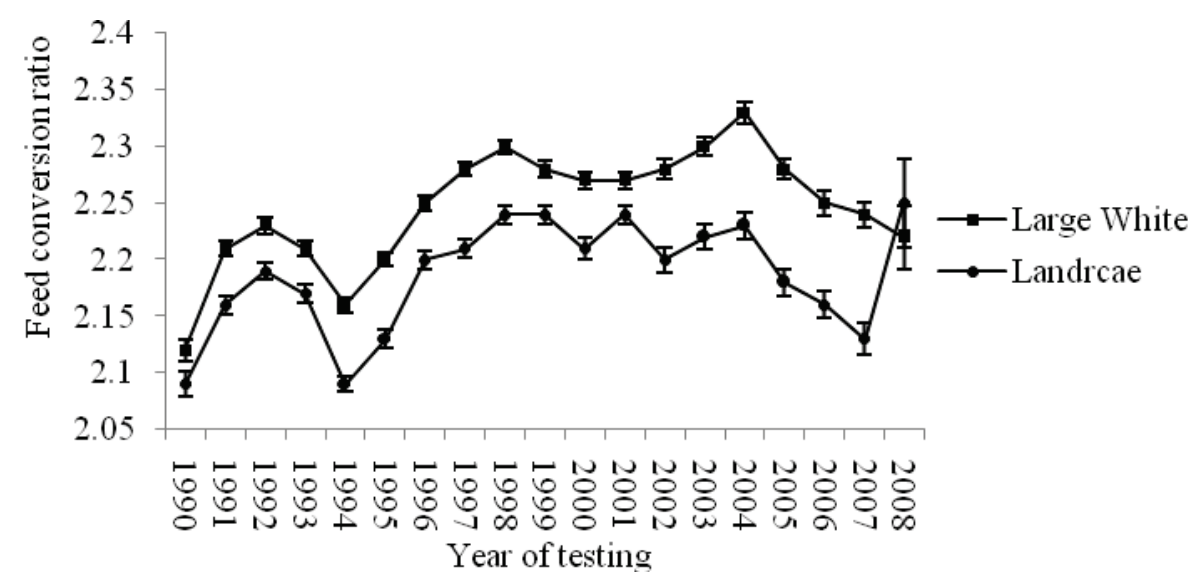

Figure 1d Phenotypic trend of feed conversion ratio in Large White and Landrace pigs.

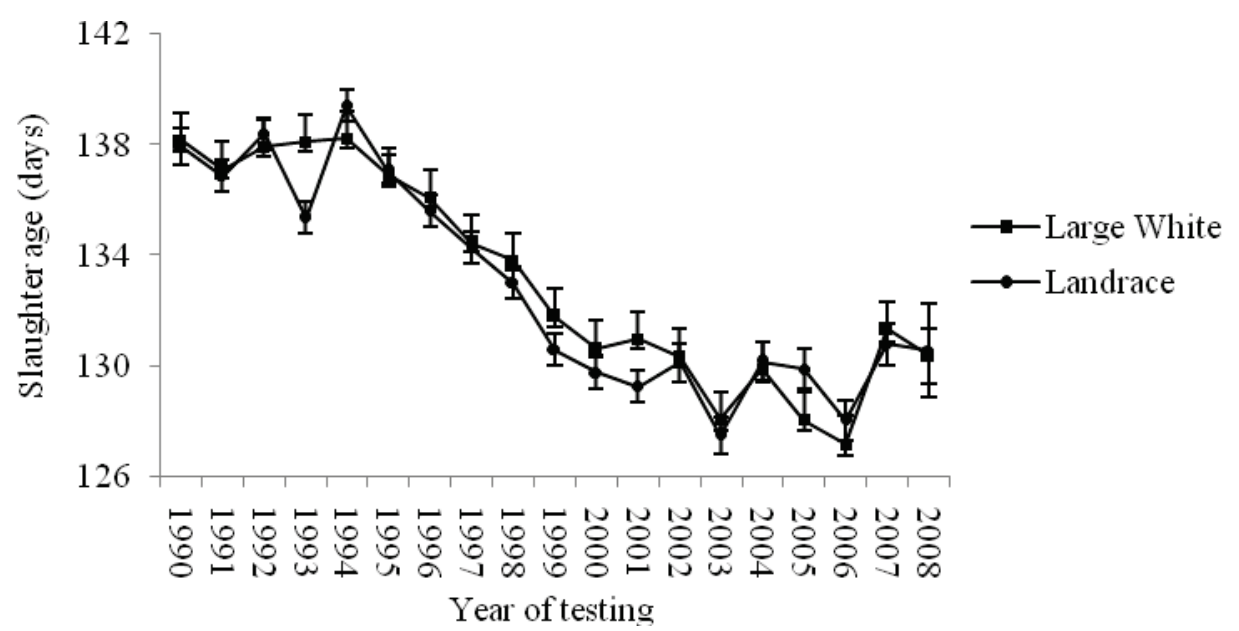

Figure 1e Phenotypic trend of age at slaughter in Large White and Landrace pigs.

pigs were fattest and leanest during spring and autumn, respectively. Winter-tested Large White pigs produced $0.28 \mathrm{~cm}$ shorter $(P<0.001)$ carcasses than summer-tested pigs. Longer $(P<0.01)$ Landrace carcasses were produced by pigs tested in summer compared to winter-tested pigs. The animals were brought to the testing station after weaning; hence the pre-test growth period for pigs tested in summer was in winter. During this season they consumed more feed to keep warm and had heavier weights (Rinaldo et al., 2000). Since these pigs were tested under similar conditions, the differences may be attributed to the carry-over effects of the pre-test rearing seasons. Such effects have been confirmed by Nilzen et al. (2001) and Gentry 
et al. (2002; 2004), who reported the effects of birth and rearing environment on carcass traits. The results from this study suggest that performance testing yielded best results when done in winter.

Table 4 shows the effects of sex on growth and carcass traits in the two breeds. Castrates had thicker $(P<0.001)$ backfat than females. This may be attributed to the larger $(P<0.001)$ quantities of feed consumed during the test period. Weight gains for castrates were less $(P<0.001)$ compared to those of females in both breeds. These results are consistent with those in literature (Weatherup et al., 1998; Latorre et al., 2003).

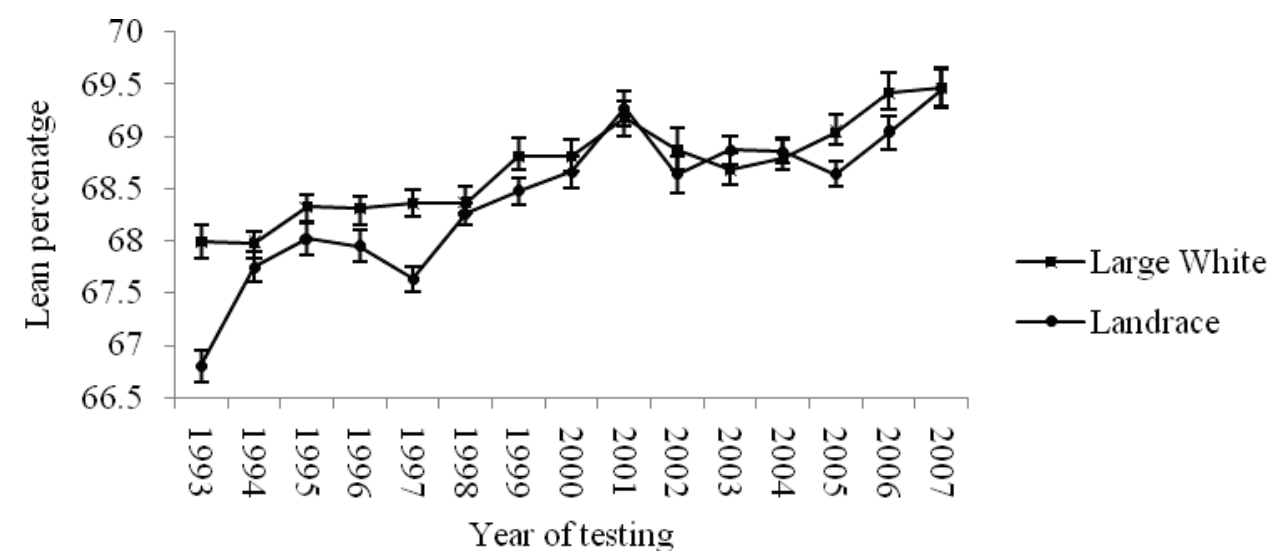

Figure 2a Phenotypic trend of lean percentage in Large White and Landrace pigs.

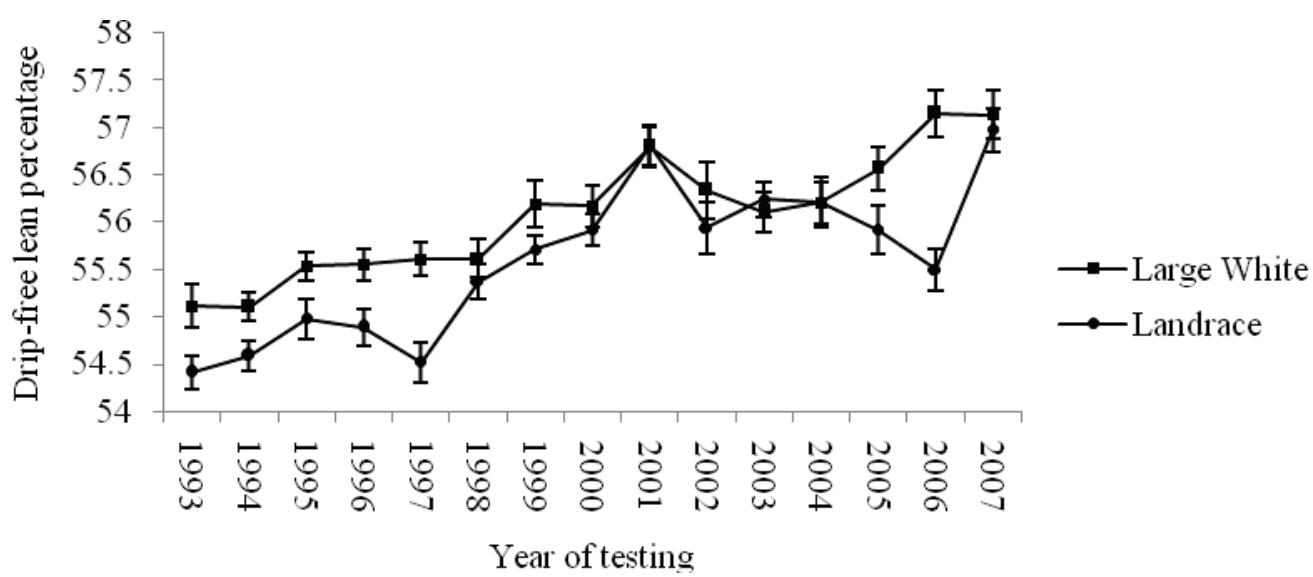

Figure 2b Phenotypic trend ofdrip-free lean percentage in Large White and Landrace pigs.

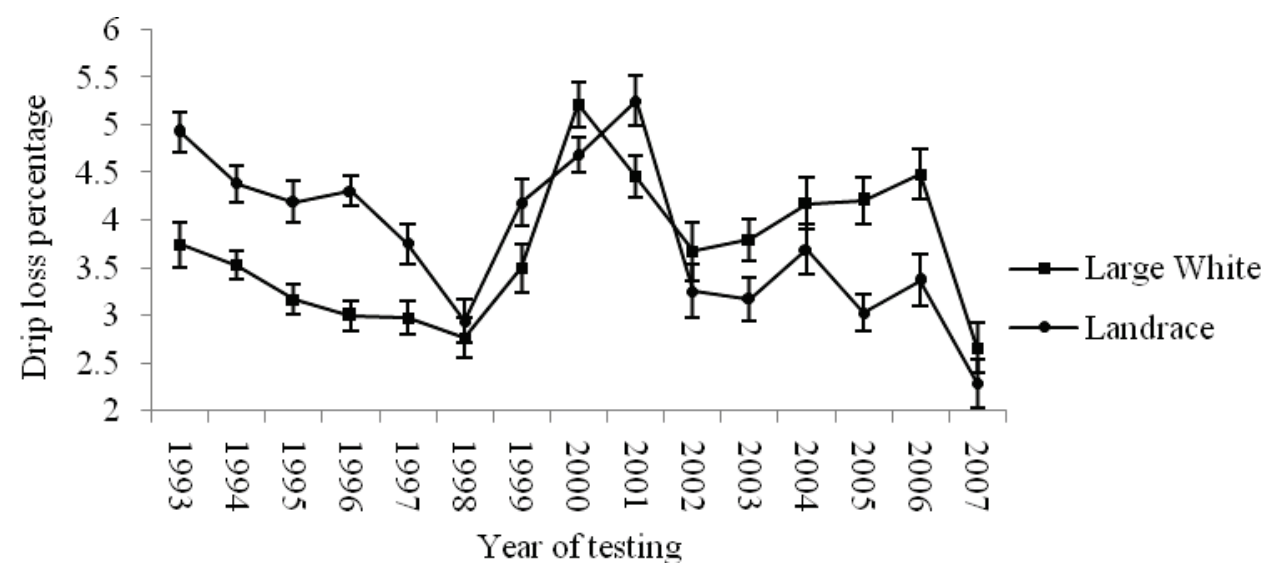

Figure 2c Phenotypic trend of drip loss percentage in Large White and Landrace pigs. 


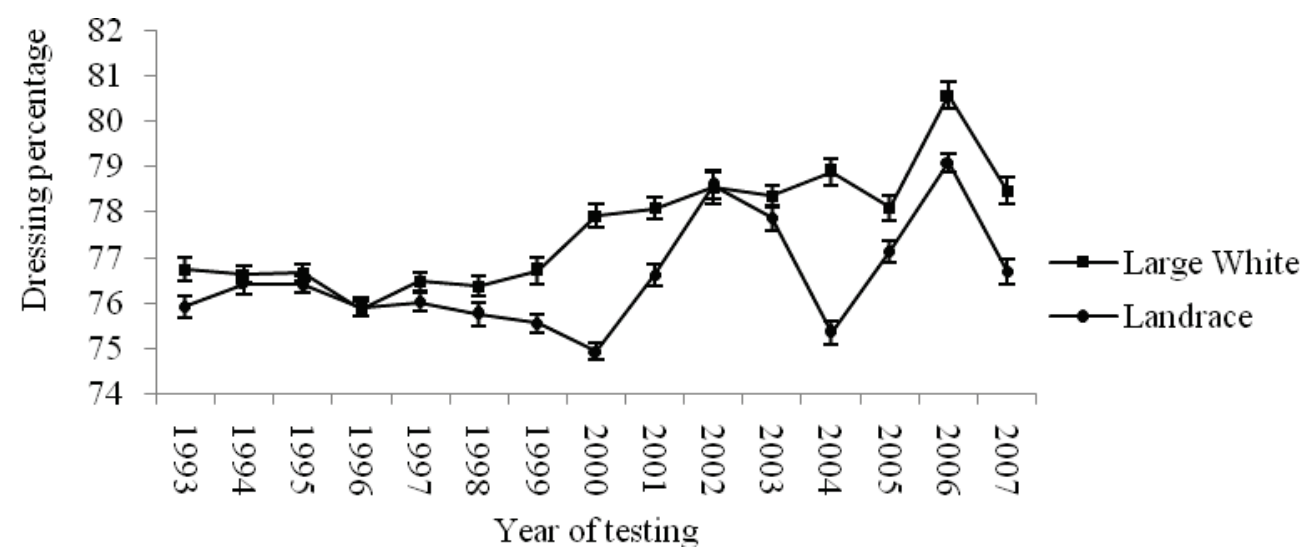

Figure 2d Phenotypic trend of dressing percentage in Large White and Landrace pigs.

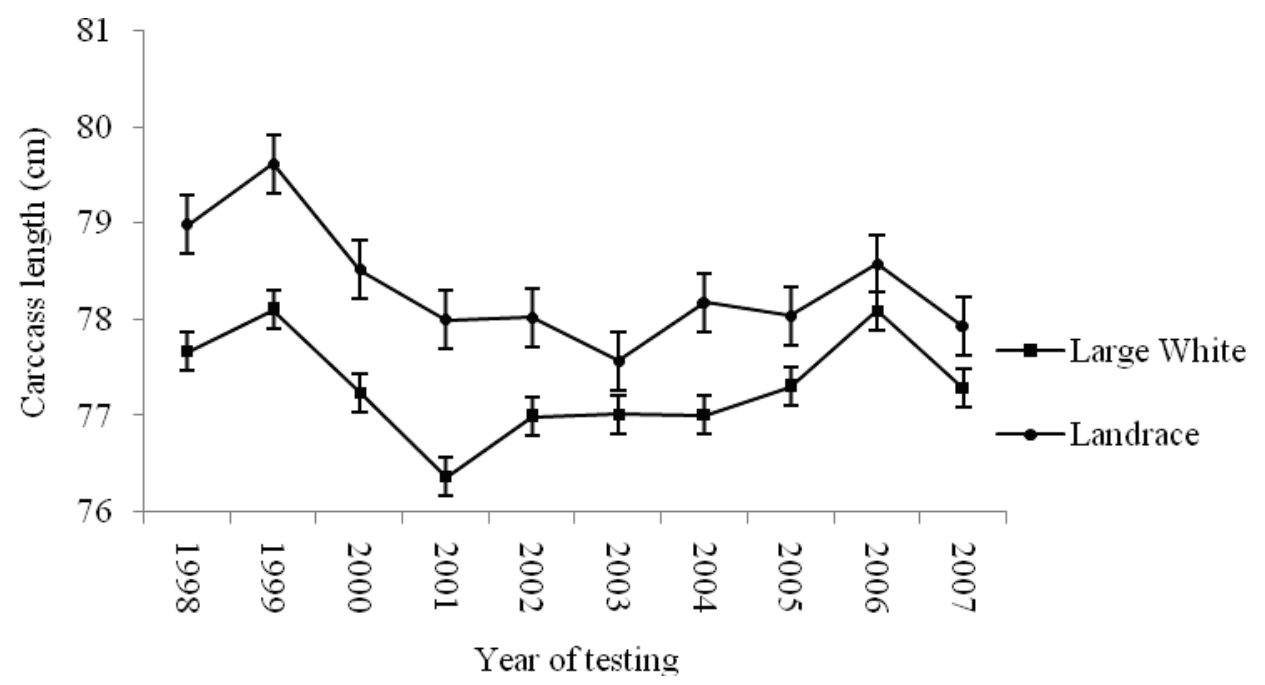

Figure 2e Phenotypic trend of carcass length in Large White and Landrace pigs.

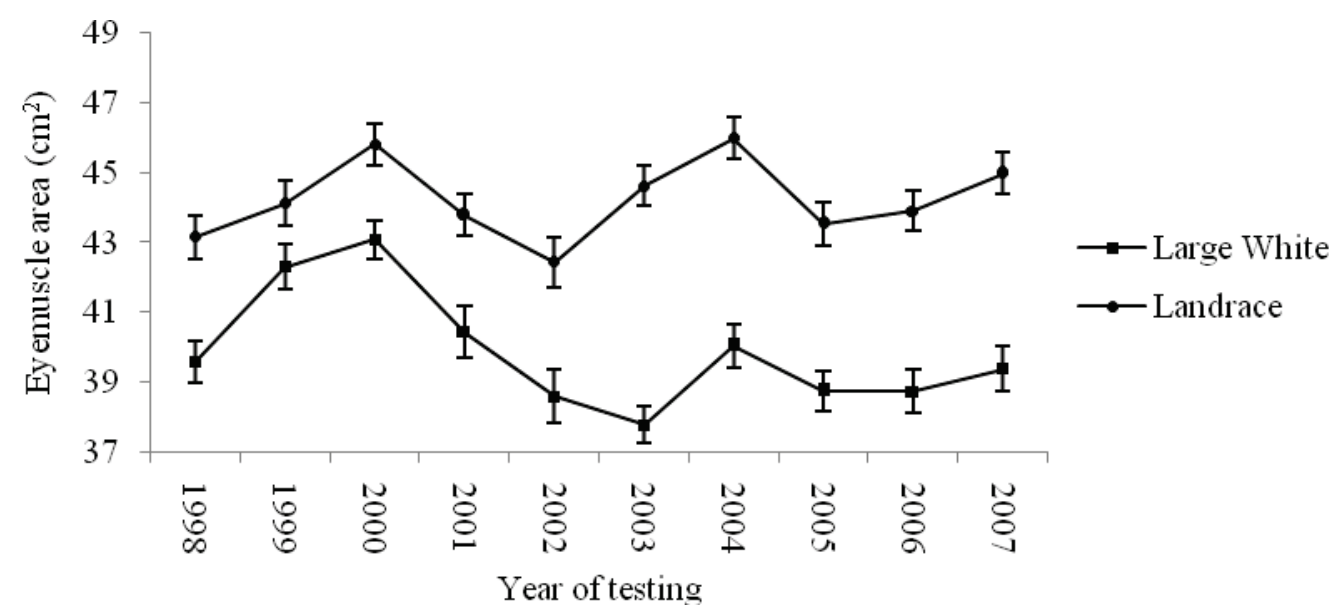

Figure 2f Phenotypic trend of eye muscle area in Large White and Landrace pigs. 
Table 3 Least squares means ( \pm SE) for the effect of season of testing on growth and carcass traits in Large White and Landrace pigs

\begin{tabular}{|c|c|c|c|c|c|c|c|c|}
\hline & \multicolumn{4}{|c|}{ Large White } & \multicolumn{4}{|c|}{ Landrace } \\
\hline & $\mathrm{N}$ & Summer & $\mathrm{N}$ & Winter & $\mathrm{N}$ & Summer & $\mathrm{N}$ & Winter \\
\hline BFAT (mm) & 9195 & $12.9^{\mathrm{a}} \pm 0.03$ & 10884 & $12.9^{\mathrm{a}} \pm 0.03$ & 5538 & $13.2^{\mathrm{a}} \pm 0.05$ & 6631 & $13.2^{\mathrm{a}} \pm 0.05$ \\
\hline TPG (g/day) & 9195 & $989.1^{\mathrm{a}} \pm 1.52$ & 10884 & $983.9^{\mathrm{a}} \pm 1.16$ & 5538 & $958.9^{\mathrm{a}} \pm 1.98$ & 6631 & $957.6^{\mathrm{a}} \pm 1.91$ \\
\hline LTG (g/day) & 9195 & $652.2^{\mathrm{a}} \pm 0.67$ & 10884 & $649.2^{\mathrm{a}} \pm 0.64$ & 5538 & $652.3^{\mathrm{a}} \pm 0.89$ & 6631 & $650.5^{\mathrm{a}} \pm 0.86$ \\
\hline FCR & 9195 & $2.22^{\mathrm{a}} \pm 0.01$ & 10884 & $2.31^{\mathrm{b}} \pm 0.01$ & 5538 & $2.16^{\mathrm{a}} \pm 0.01$ & 6631 & $2.20^{\mathrm{b}} \pm 0.01$ \\
\hline AGES (days) & 9195 & $132.8^{\mathrm{a}} \pm 0.14$ & 10884 & $133.4^{\mathrm{a}} \pm 0.13$ & 5538 & $132.9^{\mathrm{a}} \pm 0.18$ & 6631 & $133.3^{\mathrm{a}} \pm 0.17$ \\
\hline LEAN (\%) & 1926 & $68.7^{\mathrm{a}} \pm 0.06$ & 3480 & $68.7^{\mathrm{a}} \pm 0.05$ & 852 & $68.4^{\mathrm{a}} \pm 0.09$ & 1681 & $68.5^{\mathrm{b}} \pm 0.08$ \\
\hline DLEAN (\%) & 1926 & $56.1^{\mathrm{a}} \pm 0.08$ & 3480 & $56.1^{\mathrm{a}} \pm 0.08$ & 852 & $55.5^{\mathrm{a}} \pm 0.12$ & 1681 & $55.7^{\mathrm{a}} \pm 0.11$ \\
\hline DRIP (\%) & 1926 & $3.74^{\mathrm{a}} \pm 0.07$ & 3480 & $3.65^{\mathrm{a}} \pm 0.06$ & 852 & $3.88^{\mathrm{a}} \pm 0.12$ & 1681 & $3.78^{\mathrm{a}} \pm 0.11$ \\
\hline DRESS (\%) & 1926 & $77.7^{\mathrm{a}} \pm 0.09$ & 3480 & $77.5^{\mathrm{a}} \pm 0.09$ & 852 & $76.8^{\mathrm{a}} \pm 0.13$ & 1681 & $76.7^{\mathrm{a}} \pm 0.12$ \\
\hline CRLTH (cm) & 694 & $77.5^{\mathrm{a}} \pm 0.13$ & 1573 & $77.2^{\mathrm{b}} \pm 0.11$ & 342 & $78.6^{\mathrm{a}} \pm 0.19$ & 669 & $78.1^{\mathrm{b}} \pm 0.15$ \\
\hline AREA $\left(\mathrm{cm}^{2}\right)$ & 694 & $40.5^{\mathrm{a}} \pm 0.30$ & 1573 & $40.0^{\mathrm{a}} \pm 0.27$ & 342 & $44.2^{\mathrm{a}} \pm 0.38$ & 669 & $43.3^{\mathrm{b}} \pm 0.31$ \\
\hline
\end{tabular}

$\mathrm{N}$ - number of records; BFAT - backfat thickness; TPG - test period weight gain; LTG - weight gain from birth to slaughter; FCR - feed conversion ratio during test; AGES - age at slaughter; LEAN - lean percentage; DLEAN - drip-free lean; DRIP - drip loss; CRLTH - carcass length; DRESS - dressing percentage; AREA - eye muscle area.

Values with the same superscript within for breed and season are not significantly different. 
Table 4 Least squares means $( \pm$ SE) for the effect of sex on growth and carcass traits in Large White and Landrace pigs

\begin{tabular}{|c|c|c|c|c|c|c|c|c|}
\hline & \multicolumn{4}{|c|}{ Large White } & \multicolumn{4}{|c|}{ Landrace } \\
\hline & $\mathrm{N}$ & Castrates & $\mathrm{N}$ & Females & $\mathrm{N}$ & Castrates & $\mathrm{N}$ & Females \\
\hline BFAT (mm) & 5417 & $13.3^{\mathrm{a}} \pm 0.04$ & 14662 & $12.6^{b} \pm 0.03$ & 3404 & $13.5^{\mathrm{a}} \pm 0.05$ & 8765 & $12.9^{\mathrm{b}} \pm 0.04$ \\
\hline TPG (g/day) & 5417 & $948.6^{\mathrm{a}} \pm 1.75$ & 14662 & $1024.4^{\mathrm{b}} \pm 1.37$ & 3404 & $922.7^{\mathrm{a}} \pm 2.24$ & 8765 & $993.8^{\mathrm{b}} \pm 1.80$ \\
\hline LTG (g/day) & 5417 & $637.7^{\mathrm{a}} \pm 0.77$ & 14662 & $663.7^{\mathrm{b}} \pm 0.60$ & 3404 & $639.0^{\mathrm{a}} \pm 1.01$ & 8765 & $663.8^{\mathrm{b}} \pm 0.81$ \\
\hline FCR & 5417 & $2.27^{\mathrm{a}} \pm 0.01$ & 14662 & $2.24^{\mathrm{a}} \pm 0.01$ & 3404 & $2.21^{\mathrm{a}} \pm 0.01$ & 8765 & $2.23^{\mathrm{a}} \pm 0.01$ \\
\hline AGES (days) & 5417 & $135.7^{\mathrm{a}} \pm 0.16$ & 14662 & $130.5^{\mathrm{b}} \pm 0.12$ & 3404 & $135.6^{\mathrm{a}} \pm 0.20$ & 8765 & $130.6^{\mathrm{b}} \pm 0.16$ \\
\hline LEAN (\%) & 2557 & $68.6^{\mathrm{a}} \pm 0.06$ & 2849 & $68.8^{\mathrm{b}} \pm 0.06$ & 1232 & $68.4^{\mathrm{a}} \pm 0.08$ & 1301 & $68.5^{\mathrm{a}} \pm 0.08$ \\
\hline DLEAN (\%) & 2557 & $55.9^{\mathrm{a}} \pm 0.08$ & 2849 & $56.3^{\mathrm{b}} \pm 0.08$ & 1232 & $55.5^{\mathrm{a}} \pm 0.11$ & 1301 & $55.7^{\mathrm{b}} \pm 0.11$ \\
\hline DRIP (\%) & 2557 & $3.85^{\mathrm{a}} \pm 0.07$ & 2849 & $3.54^{\mathrm{b}} \pm 0.06$ & 1232 & $4.04^{\mathrm{a}} \pm 0.11$ & 1301 & $3.62^{\mathrm{b}} \pm 0.11$ \\
\hline DRESS (\%) & 2557 & $78.4^{\mathrm{a}} \pm 0.09$ & 2849 & $76.9^{\mathrm{b}} \pm 0.09$ & 1232 & $77.3^{\mathrm{a}} \pm 0.13$ & 1301 & $76.3^{\mathrm{b}} \pm 0.13$ \\
\hline CRLTH $(\mathrm{cm})$ & 1058 & $77.2^{\mathrm{a}} \pm 0.12$ & 1209 & $77.4^{\mathrm{b}} \pm 0.12$ & 488 & $78.1^{\mathrm{a}} \pm 0.17$ & 523 & $78.7^{\mathrm{b}} \pm 0.17$ \\
\hline AREA $\left(\mathrm{cm}^{2}\right)$ & 1058 & $41.6^{\mathrm{a}} \pm 0.28$ & 1209 & $39.0^{\mathrm{b}} \pm 0.27$ & 488 & $45.0^{\mathrm{a}} \pm 0.34$ & 523 & $42.5^{\mathrm{b}} \pm 0.34$ \\
\hline
\end{tabular}

BFAT - backfat thickness; TPG - test period weight gain; LTG - weight gain from birth to slaughter; FCR - feed conversion ratio during test; AGES - age at slaughter; LEAN - lean percentage; DLEAN - drip-free lean; DRIP - drip loss; CRLTH - carcass length; DRESS - dressing percentage; AREA - eye muscle area.

Values with the same superscript within row for breed and sex are not significantly different. 
Table 5 Least squares means ( \pm SE) for the effect of testing phase on growth traits in Large White and Landrace pigs

\begin{tabular}{|c|c|c|c|c|c|c|c|c|}
\hline & \multicolumn{4}{|c|}{ Large White } & \multicolumn{4}{|c|}{ Landrace } \\
\hline & $\mathrm{N}$ & Station & $\mathrm{N}$ & Farm & $\mathrm{N}$ & Station & $\mathrm{N}$ & Farm \\
\hline BFAT (mm) & 5890 & $13.9^{\mathrm{a}} \pm 0.04$ & 14189 & $11.9^{\mathrm{b}} \pm 0.04$ & 3152 & $14.8^{\mathrm{a}} \pm 0.05$ & 9017 & $11.6^{\mathrm{b}} \pm 0.05$ \\
\hline TPG (g/day) & 5890 & $993.5^{\mathrm{a}} \pm 1.62$ & 14189 & $979.5^{\mathrm{b}} \pm 1.63$ & 3152 & $944.9^{\mathrm{a}} \pm 2.13$ & 9017 & $971.6^{\mathrm{b}} \pm 2.06$ \\
\hline LTG (g/day) & 5890 & $654.7^{\mathrm{a}} \pm 0.71$ & 14189 & $646.7^{\mathrm{a}} \pm 0.72$ & 3152 & $648.1^{\mathrm{a}} \pm 0.96$ & 9017 & $654.7^{\mathrm{a}} \pm 0.93$ \\
\hline FCR & 5890 & $2.33^{\mathrm{a}} \pm 0.01$ & 14189 & $2.18^{\mathrm{b}} \pm 0.01$ & 3152 & $2.32^{\mathrm{a}} \pm 0.01$ & 9017 & $2.12^{\mathrm{b}} \pm 0.01$ \\
\hline AGES (days) & 5890 & $131.2^{\mathrm{a}} \pm 0.15$ & 14189 & $133.5^{\mathrm{b}} \pm 0.15$ & 3152 & $130.1^{\mathrm{a}} \pm 0.19$ & 9017 & $131.0^{b} \pm 0.19$ \\
\hline
\end{tabular}

BFAT - backfat thickness; TPG - test period weight gain; LTG - weight gain from birth to slaughter; FCR - feed conversion ratio during test; AGES - age at slaughter; values with the same superscript within row for breed and phase are not significantly different.

Table 6 Regression coefficients of feed intake and age at the beginning of test on growth and carcass traits

\begin{tabular}{|c|c|c|c|c|c|c|c|c|}
\hline & \multicolumn{4}{|c|}{ Large White } & \multicolumn{4}{|c|}{ Landrace } \\
\hline & $\mathrm{N}$ & FEED (kg) & $\mathrm{N}$ & AGEB (days) & $\mathrm{N}$ & FEED (kg) & $\mathrm{N}$ & AGEB (days) \\
\hline BFAT (mm) & 21000 & $0.027 \pm 0.001$ & 21000 & $-0.014 \pm 0.002$ & 12169 & $0.030 \pm 0.001$ & 12169 & $-0.021 \pm 0.003$ \\
\hline TPG (g/day) & 21000 & $-2.438 \pm 0.044$ & 21000 & $-0.984 \pm 0.103$ & 12169 & $-2.521 \pm 0.052$ & 12169 & $-0.763 \pm 0.124$ \\
\hline LTG (g/day) & 21000 & $-0.436 \pm 0.015$ & 21000 & $-4.268 \pm 0.036$ & 12169 & $-0.523 \pm 0.020$ & 12169 & $-4.227 \pm 0.046$ \\
\hline FCR & & ns & & ns & & ns & & ns \\
\hline AGES (days) & 2100 & $0.141 \pm 0.004$ & & $¥$ & 12169 & $0.124 \pm 0.004$ & & $¥$ \\
\hline LEAN (\%) & 5406 & $-0.037 \pm 0.001$ & 5406 & $-0.021 \pm 0.004$ & 2534 & $-0.031 \pm 0.002$ & 2534 & $-0.028 \pm 0.008$ \\
\hline DLEAN (\%) & 5406 & $-0.051 \pm 0.002$ & 5406 & $-0.031 \pm 0.006$ & 2534 & $-0.043 \pm 0.003$ & 2534 & $-0.035 \pm 0.010$ \\
\hline DRIP (\%) & 5406 & $-0.010 \pm 0.002$ & & $0.007 \pm 0.003$ & & ns & & ns \\
\hline DRESS (\%) & 5406 & $-0.065 \pm 0.008$ & & ns & 2534 & $-0.031 \pm 0.013$ & & ns \\
\hline CRLTH (cm) & & ns & & ns & & ns & & ns \\
\hline $\operatorname{AREA}\left(\mathrm{cm}^{2}\right)$ & & ns & & ns & & ns & & ns \\
\hline
\end{tabular}

N - number of records; BFAT - backfat thickness; TPG - test period weight gain; LTG - weight gain from birth to slaughter; FCR - feed conversion ratio during test; AGES - age at slaughter; LEAN - lean percentage; DLEAN - drip-free lean; DRIP - drip loss; CRLTH - carcass length; DRESS dressing percentage; AREA - eye muscle area; FEED - total feed intake during test period; AGEB - age at the beginning of the test period; ns - effect not significant; $¥-$ effect not included in the analysis. 
Contrary to this, Augspurger et al. (2002) reported better growth rates in males and attributed it to their greater feed intake. Although there were no sex differences in feed conversion ratio in the current study, Nieuwhof et al. (1991), Friesen et al. (1994) and Latorre et al. (2003) observed poorer feed conversion efficiencies in males. Females were leaner $(P<0.001)$ than castrates in both breeds, while smaller $(P<0.01)$ eye muscle areas were observed in females. Serrano et al. (2008) observed that castrates produced more carcass yield, were fatter and had shorter carcasses. Castrates have a low capacity for protein deposition and a high rate of fat accretion (Campbell \& Taverner, 1985). Mayoral et al. (1999) and Lattore et al. (2003) found no differences in carcass characteristics attributable to sex. These results may favour the testing of females.

The effect of the testing environment on growth traits is shown Table 5 where animals were tested at the central testing station (Phase B) and the farms (Phase D), respectively. Phase D animals were leaner $(P<0.001)$ than Phase B animals in both breeds. Animals tested under Phase B had better $(P<0.001)$ feed conversion ratios than Phase $\mathrm{D}$ animals. This may have resulted in higher $(P<0.001)$ growth rates observed in Phase B animals which caused these animals to reach slaughter weight earlier $(P<0.001)$. The differences in growth performance due to the testing phase may be attributable to differences between the two testing environments. Rearing environment has been reported to influence subsequent growth performance (Beattie et al., 2000; Gentry et al., 2004). The differences in performance between the phases show that central performance testing is more beneficial. The effect of testing phase may be confounded in the herd effect for Phase D animals, but not for those in Phase B. Although there are differences due to testing environment, data from both environments should be analyzed jointly. Traits from each testing environment can only be analyzed as different traits if they are genetically different.

The effect of feed intake on growth and carcass traits is shown in Table 6. Total test period feed intake was associated with reductions $(P<0.001)$ in weight gains. Contrasting results showing increased weight gains with an increasing level of daily feed intake have been reported (Garcia-Valverde et al., 2008). This may suggest that animals consuming less feed under ad libitum conditions are more efficient. Increasing backfat thickness due to increased total test period feed intake observed in the current study is consistent with the observations of Garcia-Valverde et al. (2008). This can be attributed to the increased activity of lipogenic enzymes associated with increased energy intake (Daza et al., 2007). This observation suggests that there is an optimum feed intake to achieve the desired growth performance. Increasing total test period feed intake was associated with decreasing $(P<0.001)$ lean percentage, drip-free lean percentage, drip loss and dressing percentage. These results are in agreement with earlier reports (Affentranger et al., 1996; Akdag et al., 2008). Nutrient digestibility increases with level of feed intake (Haydon et al., 1984) and the absorbed nutrients are used for maintenance and lean gain (Scharlach \& Kleyn, 1996). When energy consumption exceeds requirements, the extra energy is converted to fat and stored (Scharlach \& Kleyn, 1996). The differences may be attributed to the fact that total test period feed intake was used in the current study instead of average daily feed intake. Pigs that grow slowly have a longer test period and therefore require more total feed. On a daily basis, slow growth is associated with less daily feed intake.

Table 9 contains the effects of age at the beginning of the test on growth and carcass traits. Age at the beginning of the test period affected $(P<0.001)$ backfat thickness, growth rates and lean percentages. Daza et al. (2007) reported contrasting results, where higher growth rates were observed in pigs that entered the test at an older age. They attributed this to compensatory growth whereby pigs that had shown slower growth rates during the pre-test period, had faster growth during test period. Average daily gain and carcass weight, as a consequence of older age at the beginning of the free-range fattening period have been previously reported (Daza et al., 2007). Variations in carcass characteristics due to age have been reported (Mayoral et al., 1999; Daza et al., 2005; 2007). Contrary to the present results, younger pigs at the beginning of the fattening period had inferior carcass characteristics in Iberian pigs (Daza et al., 2007). These results portray an unfavourable relationship between starting age and weight gains. An optimum age should be established for commencing testing in these pig populations. Observations from the current study may encourage the testing of younger animals at the beginning of the test.

The only interaction observed in this study was between herd of origin and year of testing, which affected $(P<0.001)$ all growth and carcass traits in the two breeds. This suggests that there are inconsistent carcass characteristics in animals tested from different herds over the years. These results are consistent with those reported by Cassady et al. (2004). Wallenbeck et al. (2009) observed a herd-year-season interaction when they investigated the genotype $\times$ environment interaction in Hampshire boars. These results emphasize 
the influences of pre-testing period treatments on growth performance and carcass characteristics being carried over to slaughter, despite uniform treatment during the test period. Therefore, these effects may be combined during genetic evaluation to adjust for their effect on carcass traits.

\section{Conclusion}

There is a paucity of information on non-genetic factors affecting carcass characteristics of centrally tested pigs in South Africa. The purpose of this study was to evaluate the non-genetic effects on growth and carcass traits within the two major South African commercial pig breeds. These results point out that optimum management at farm level is a prerequisite for optimum growth performance and carcass quality and yield, which cannot be compensated for by on-test treatments. Castrates produce higher carcass yields, while females produce better carcass quality. If growth performance and carcass characteristics are to be improved, central performance testing should be done on females at a younger age in winter. Feeding the pigs ad libitum during testing may be counterproductive and separate genetic evaluation procedures for the two testing phases may be necessary. Younger pigs at the start of test may be preferable to improve carcass leanness and yield. The results discourage feeding pigs ad libitum if carcass quality is to be improved, but carcass yield is unaffected. Investigation of the effect of feed intake on growth and carcass traits in these pig populations may be improved by use of test-day data. These results underline the need to adjust for fixed effects when performing genetic evaluations in these pig populations.

\section{Acknowledgements}

The data for this research was supplied by the INTERGIS hosted by the Agricultural Research Council Livestock Business Division in Irene, Pretoria. Special thanks are to S.F. Voordewind, the Technical Manager for Pig \& Poultry Recording and Improvement Scheme, AR-AP. The North West University is duly acknowledged as it made this study a success.

\section{References}

Affentranger, P., Gerwig, C., Seewer, G.J.F., Schwurer, D. \& Kunzi, N., 1996. Growth and carcass characteristics as well as meat and fat quality of three types of pigs under different feeding regimens. Livest. Prod. Sci. 45, 187-196.

Akdag, F., Elmaz, O., Kutay, C. \& Demir, H., 2008. Effect of different diets on growth performance and feed efficiency in early weaned piglets. Turk. J. Vet. Anim. Sci. 32 (1), 7-11.

Beattie, V.E., O'Connell, N.E. \& Moss, B.W., 2000. Influence of environmental enrichment on the behavior, performance and meat quality of domestic pigs. Livest. Prod. Sci. 65, 71-79.

Bee, G., 2004. Effect of early gestation feeding, birth weight, and gender of progeny on muscle fiber characteristics of pigs at slaughter. J. Anim. Sci. 82, 826-836.

Bogosavljvic-Boskovic, S., Kurcbic, S., Petrovic, M.D. \& Radovic, V., 2006. The effect of sex and rearing system on carcass composition and cut yields of broiler chickens. Czech J. Anim. Sci. 1, 31-38.

Bruwer, G.G., 1992. The evaluation of pig carcasses for the development of a classification system. Ph.D (Agric) thesis, University of Pretoria, South Africa.

Cameron, N.D., 1994. Selection for components of efficient lean growth rate in pigs. I. Selection pressure applied and direct responses in a Large White herd. Anim. Prod. 59, 263-269.

Campbell, R.G. \& Taverner, M.R., 1985. Effects of strain and sex on protein and energy metabolism in growing pigs. In: Energy Metabolism of Farm Animals. Eds Moe, P.W., Tyrrell, H.F. \& Reynolds, P.J., Eur. Assoc. Anim. Prod., Publ. No. 32, Rowan and Littlefield. USA. p. 78.

Cassady, J.P., Robison, O.W., Johnson, R.K., Mabry, J.W., Christian, L.L., Tokach, M.D., Miller, R.K. \& Goodwin, R.N., 2004. National pork producers council maternal line genetic evaluation: A comparison of growth and carcass traits in terminal progeny. J. Anim. Sci. 82, 3482-3485.

Chikwanha, O.C., Halimani, T.E., Chimonyo, M., Dzama, K. \& Bhebhe, E., 2007. Seasonal changes in body condition scores of pigs and chemical composition of pig feed resources in a semiarid smallholder farming area of Zimbabwe. Afr. J. Agric. Res. 2, 468-474.

Chimonyo, M. \& Dzama, K., 2007. Estimation of genetic parameters for growth performance and carcass traits in Mukota pigs. Animal 1, 317-323. 
Close, W.H., 1987. The influence of the thermal environment on the productivity of pigs. In: Pig Housing and the Environment. Eds Smith, A.T. \& Lawrence, T.L.J., Occ. Publ., Br. Soc. Anim. Prod. No. 11. pp. 9-24.

Daza, A., Lopez-Bote, C.J., Olivares, A., Menoyo, D. \& Ruiz, J., 2007. Age at the beginning of the fattening period of Iberian pigs under free-range conditions affects growth, carcass characteristics and the fatty acid profile of lipids. Anim. Feed. Sci. Technol. 139, 81-91.

Daza, A., Mateos, A., Rey, A.I. \& López Bote, C.J., 2005. Effect of feeding level during the period previous to free-range fattening on growth and carcass characteristics in Iberian pigs. Spanish J. Agric. Res. 3 (4), 387-395.

Foxcroft, G.R., Dixon, W.T., Novak, S., Putman, C.T., Town, S.C. \& Vinsky, M.D.A., 2006. The biological basis for prenatal programming of postnatal performance in pigs. J. Anim. Sci. 84, E105-E114.

Friesen, K.G., Nelssen, J.L., Unruh, J.A., Goodband, R.D. \& Tokach, M.D., 1994. Effects of the interrelationship between genotype, sex, dietary lysine on growth performance and carcass composition in finishing pigs fed either 104 or 127 kilograms. J. Anim. Sci. 72, 946-954.

García-Valverde, R., Barea, R., Lara, L., Nieto, R. \& Aguilera, J.F., 2008. The effects of feeding level upon protein and fat deposition in Iberian heavy pigs. Livest. Sci. 114, 263-273.

Gentry, J.G., McGlone, J.J., Blanton, J.R. \& Miller, M.F., 2002. Alternative housing systems for pigs: Influences on growth, composition and pork quality. J. Anim. Sci. 80, 1781-1790.

Gentry, J.G., McGlone, J.J., Miller, M.F. \& Blanton Jr, J.R., 2004. Environmental effects on pig performance, meat quality, and muscle characteristics. J. Anim. Sci. 82, 209-217.

Hansen, L.L., Claudi-Magnussen, C., Jensen, S.K. \& Andersen, H.J., 2006. Effect of organic pig production systems on performance and meat quality. Meat Sci. 74, 605-615.

Haydon, K.D., Knabe, D.A. \& Tanksley Jr., T.D., 1984. Effects of level of feed intake on nitrogen, amino acid and energy digestibilities measured at the end of the small intestine and over the total digestive tract of growing pigs. J. Anim. Sci. 59, 717-724.

Hoque, M.A., Kadowak, H., Shibata, T., Oikawa, T. \& Suzuki, K., 2007. Genetic parameters for measures of residual feed intake and growth traits in seven generations of Duroc pigs. J. Anim. Breed. Genet. 124, 108-116.

Johnson, Z.B., Chewning, J.J. \& Nugent III, R.A., 1999. Genetic parameters for production traits and measures of residual feed intake in Large White swine. J. Anim. Sci. 77, 1679-1685.

Larzul, C., Lefaucheur, L., Ecolan, P., Gogue, J., Talmant, A., Sellier, P., Le Roy, P. \& Monin, G., 1997. Phenotypic and genetic parameters for longissimus muscle fiber characteristics in relation to growth, carcass, and meat quality traits in Large White pigs. J. Anim. Sci. 75, 3126-3137.

Latorre, M.A., García-Belenguer, E. \& Ariño, L., 2003. The effects of sex and slaughter weight on growth performance and carcass traits of pigs intended for dry-cured ham from Teruel (Spain). J. Anim. Sci. 86, 1933-1942.

Le Dividich, J., Noblet, J. \& Bikawa, T., 1987. Effect of environmental temperature and dietary energy concentration on the performance and carcass characteristics of growing-finishing pigs fed to equal rate of gain. Livest. Prod. Sci. 17, 235-246.

Li, X. \& Kennedy, B.W., 1994. Genetic parameters for growth rate and backfat in Canadian Yorkshire, Landrace, Duroc and Hampshire pigs. J. Anim. Sci. 72, 1450-1454.

Mahgoub, O., Kadim, I.T., Al-Saqry, N.M. \& Al-Busaidi, R.M., 2004. Effects of body weight and sex on carcass tissue distribution in goats. Meat Sci. 67, 577-585.

Mayoral, A.I., Dorado, M., Guill’en, M.T., Robina, A., Vivo, J.M., V’azquez, C. \& Ruiz, J., 1999. Development of meat and carcass quality characteristics in Iberian pigs reared outdoor. Meat Sci. 52, 315-324.

McPhee, C.P. \& MacBeth, M., 2000. A profit model for estimating economic values of traits in the National Pig Improvement Program, PDRC DAG58/1339 final report.

McPhee, C.P., Williams, K.C. \& Daniels, L.J., 1991. The effect of selection for rapid lean growth on the dietary lysine and energy requirements of pigs fed to scale. Livest. Prod. Sci. 27, 185-198.

Mungate, F., Dzama, K., Mandisodza, K. \& Shoniwa, A. 1999. Some non-genetic factors affecting commercial pig production in Zimbabwe. S. Afr. J. Anim. Sci. 29, 164-173.

Nephawe, K.A., Maiwashe, A. \& Theron, H.E., 2006. The effect of herd of origin by year on post-weaning traits of young beef bulls at centralized testing centres in South Africa. S. Afr. J. Anim. Sci. 36, 33-39. 
Nieuwhof, G.J., Kanis, E., Van der Hel, W., Vestergen, M.W.A., Huisman, J. \& Van der Wal, P., 1991. Effect of recombinant porcine somatotropin on body composition and meat quality in growing pigs; interactions with genotype, sex and slaughter weight. Meat Sci. 30, 265-278.

Nilzen, V., Babol, J., Dutta, P.C., Lundeheim, N., Enfalt, A.C. \& Lundstrom, K., 2001. Free range rearing of pigs with access to pasture grazing - effect on fatty acid composition and lipid oxidation products. Meat Sci. 58, 267-275.

Oh, S.H., Lee, D.H. \& See, M.T., 2005. Genetic Correlations Between Growth and Carcass Traits. North Carolina State University Animal Science Departmental Report, USA.

Petersen, J.S., Henckel, P., Maribo, H., Oksbjerg, N. \& Sørensen, M.T., 1997. Muscle metabolism, post mortem pH-decline and meat quality in pigs subjected to regular physical training and spontaneous activity. Meat Sci. 46, 259-275.

Ramaekers, P.J.L., Swinkels, J.W.G.M., Huiskes, J.H., Verstegen, M.W.A., Den Hartog, L.A. \& Van der Peet-Schwering, C.M.C., 1996. Performance and carcass traits of individual pigs housed in groups as affected by ad libitum and restricted feeding. Livest. Prod. Sci. 47, 43-50.

Rinaldo, D., Le Dividicb, J. \& Noblet, J., 2000. Adverse effects of tropical climate on voluntary feed intake and performance of growing pigs. Livest. Prod. Sci. 66, 223-234.

SAS, 2003. SAS User’s Guide. SAS Institute Inc., Cary, N.C., USA.

Scharlach, W. \& Kleyn, R., 1996. Commercial Pig Nutrition in Southern Africa. SPESFEED, South Africa.

Serrano, M.P., Valencia, D.G., Nieto, M., Lazaro, R. \& Mateos, G.G., 2007. Influence of sex and terminal sire line on performance and carcass and meat quality of Iberian pigs reared under intensive production systems. Meat Sci. 78, 420-428.

Serrano, M.P., Valencia, D.G., Fuentetaj, A., Lázaro, R. \& Mateos, G.G., 2008. Effect of gender and castration of females and slaughter weight on performance and carcass and meat quality of Iberian pigs reared under intensive management systems. Meat Sci. 80, 1122-1128.

Trezona, M., Mullan, B.P., D'Antuono, M., Wilson, R.H. \& Williams, I.H., 2004. The causes of seasonal variation in backfat thickness of pigs in Western Australia. Aust. J. Agric. Res. 55, 273-277.

Wallenbeck, A., Rydhmer, L. \& Lundeheim, N., 2009. G x E interactions for growth and carcass leanness: Re-ranking of boars in organic and conventional pig production. Livest. Sci. 123, 154-160.

Webster, A.J.F., 1977. Selection for leanness and energetic efficiency of growth in meat animals. Proc. Nutr. Soc. 36, 53-59. 